\title{
Efficient Catalytic Production of Biodiesel with Acid-Base Bifunctional Rod-Like Ca-B Oxides by the Sol-Gel Approach
}

\author{
Anping Wang ${ }^{1,2}, \mathrm{Hu} \mathrm{Li}^{1}{ }^{1} * \mathbb{C}$, Heng Zhang ${ }^{1}, \mathrm{Hu}$ Pan ${ }^{1}$ and Song Yang ${ }^{1, * \mathbb{C}}$ \\ 1 State Key Laboratory Breeding Base of Green Pesticide \& Agricultural Bioengineering, Key Laboratory of \\ Green Pesticide \& Agricultural Bioengineering, Ministry of Education, State-Local Joint Laboratory for \\ Comprehensive Utilization of Biomass, Center for Research \& Development of Fine Chemicals, \\ Guizhou University, Guiyang, Guizhou 550025, China; gs.apwang16@gzu.edu.cn (A.W.); \\ gs.hengzhang16@gzu.edu.cn (H.Z.); gs.hpan15@gzu.edu.cn (H.P.) \\ 2 Key Laboratory for Information System of Mountainous Area and Protection of Ecological Environment of \\ Guizhou Province, Guizhou Normal University, Guiyang, Guizhou 550025, China \\ * Correspoondence: hli13@gzu.edu.cn (H.L.); jhzx.msm@gmail.com (S.Y.); \\ Tel.: +86-851-8829-2171 (H.L. \& S.Y.); Fax: +86-851-8829-2170 (H.L. \& S.Y.)
}

Received: 18 November 2018; Accepted: 23 December 2018; Published: 27 December 2018

check for updates

\begin{abstract}
The search for acid-base bifunctional catalysts has become a hot topic in the preparation of biofuels from renewable resources. In the present work, a series of novel acid-base bifunctional metal-boron catalysts were successfully prepared by a sol-gel method and characterized by XRD, IR, SEM, TEM, TGA, BET, and TPD. Among those bifunctional solid materials, the Ca-B(700) catalyst had the highest density of both acid and base sites and showed excellent catalytic performance in the production of biodiesel from nonedible oils with high acid value. Under the optimal reaction conditions of $20 / 1$ methanol/oil mole ratio and $4 \mathrm{wt} \%$ catalyst dosage at $105{ }^{\circ} \mathrm{C}$ for $2 \mathrm{~h}$, a high biodiesel yield of $96.0 \%$ could be obtained from Jatropha curcas oil in one-pot. In addition, $\mathrm{Ca}-\mathrm{B}(700)$ was also applicable to producing biodiesel from Firmiana platanifolia L.f. oil in a relatively low acid value, with an almost quantitative yield $(98.5 \%)$ at $65{ }^{\circ} \mathrm{C}$ after $2 \mathrm{~h}$. The Ca-B(700) catalyst had good stability and reusability, which is a promising acid-base bifunctional catalytic material for the preparation of biodiesel.
\end{abstract}

Keywords: sol-gel synthesis; acid-base bifunctional materials; high/low acid value oils; transesterification; biofuels

\section{Introduction}

In recent years, with the gradual reduction of fossil fuels, people began to pay more and more attention to the use of alternative renewable energy derived from biomass [1,2]. Among the developed biofuels, biodiesel is considered as an excellent substitute for fossil diesel, which can reduce greenhouse gas and pollutant emissions [3]. The main component of biodiesel is fatty acid methyl esters (FAME) or ethyl esters (FAEE), which are a green, eco-friendly, bio-degradable clean energy [4]. The main raw materials of biodiesel are vegetable oils, animal fat, and waste oils [5,6]. Cheaper raw materials have a great promotional effect on controlling the price of biodiesel. A variety of nonedible oils, such as Jatropha curcas, Euphorbia lathyris [5], Firmiana platanifolia [7], Xanthium sibiricum [8], and Koelreuteria integrifoliola [9], have been developed as raw materials to prepare biodiesel. Unfortunately, many oils have high acid values, which requires high-performance and robust catalysts. Biodiesel is typically obtained by esterification and transesterification of raw materials in the presence of acid or base catalysts. Particularly, heterogeneous catalysts, which are environmentally friendly 
and noncorrosive to production equipment, show more promising applications in the production of biodiesel and are being replaced traditional homogeneous catalysts [10,11].

Due to the existence of free fatty acids (FFAs), most of the raw materials have high acid values, which require the use of acidic catalysts to mediate the reaction processes. However, acidic catalysts need higher temperatures and/or longer times, which will increase the cost of industrial production. Therefore, it is desirable to avoid using acid catalysts as much as possible in the production of biodiesel from the raw materials with high acid values [12]. In turn, alkali catalysts seem to be more suitable candidates, while the problem of saponification in the (trans)esterification of raw materials with high acid values has not been well solved. In this regard, acid-base bifunctional catalysts, such as $\mathrm{Zn}_{8} @ \mathrm{Fe}-\mathrm{C}_{400}$ nanoparticles [3], K-ITQ-6 [13], and CaO- $\mathrm{La}_{2} \mathrm{O}_{3}$ [14], began to be developed for producing biodiesel. Nevertheless, these reaction systems still need high reaction temperatures or high catalyst dosages. Based on the above discussions, the exploration of acid-base bifunctional catalysts to produce biodiesel under mild conditions exhibits great potential for industrial application.

The sol-gel method is one of most widely used and effective synthesis methods in the preparation of acid-base bifunctional metal oxide catalysts $[15,16]$. The preparation of metal oxide catalysts by the sol-gel method has the advantages of simple synthesis procedure, good stability, uniformity of adulteration, and low temperature plasticity $[17,18]$, which appears more conducive to the pronounced catalytic performance of solid functional materials.

In the process of preparing biodiesel from high acid value raw materials, a small amount of water will be produced due to esterification reaction. Therefore, the catalyst has a certain hydrophobicity which makes it more excellent on catalytic performance [6]. According to previous reports $[19,20]$, the metal oxide itself has a certain hydrophobicity, which protects the catalyst from deactivation in the reaction process. Therefore, on the basis of ensuring the catalytic performance, it is necessary to study the hydrophobic properties of catalytic materials. At the same time, the modification of catalysts to obtain materials with better hydrophobic function is the focus of our follow-up research.

In this study, a series of metal-boron oxide materials were prepared by the gel-sol method and were found to have regular morphology and good stability. Among these acid-base bifunctional oxides, the smooth rod-like Ca-B catalysts exhibited superior catalytic performance in the production of biodiesel from Jatropha curcas oil with high acid values. The reaction parameters were systematically investigated and optimized, and the optimal $\mathrm{Ca}-\mathrm{B}(700)$ was found to be robust and stable for biodiesel production from the nonedible oils with either high or low acid value.

\section{Materials and Methods}

\subsection{Materials}

$\mathrm{Ca}\left(\mathrm{NO}_{3}\right)_{2} \cdot 4 \mathrm{H}_{2} \mathrm{O}(99 \%), \mathrm{Mg}\left(\mathrm{NO}_{3}\right)_{2} \cdot 6 \mathrm{H}_{2} \mathrm{O}(99 \%), \mathrm{Zn}\left(\mathrm{NO}_{3}\right)_{2} \cdot 6 \mathrm{H}_{2} \mathrm{O}(99 \%)$, and boric acid $\left(\mathrm{H}_{3} \mathrm{BO}_{3}\right.$, $\geq 99.5 \%$ ) were purchased from Shanghai Aladdin Reagent Co., Ltd. $\mathrm{ZrOCl}_{2} \cdot 8 \mathrm{H}_{2} \mathrm{O}(\geq 98 \%), \mathrm{AlCl}_{3} \cdot 6 \mathrm{H}_{2} \mathrm{O}$ $(99 \%)$, and polyethylene-polypropylene glycol (F68) were obtained from Beijing J\&K Scientific Ltd. $\mathrm{MeOH}(\geq 99.5 \%)$, potassium hydroxide $(\mathrm{KOH}, \geq 85.0 \%)$, ethanol $(\geq 99.7 \%)$, and petroleum ether $\left(60-90^{\circ} \mathrm{C}\right)$ were purchased from Chuandong Chemical Reagent Co., Ltd. The crude oils of Jatropha curcas L. and Firmiana platanifolia L.f. were prepared by our group [5,7]. The acid values of obtained oils were evaluated by titration according to the national standard with $0.1 \mathrm{M}$ ethanol solution of potassium hydroxide.

\subsection{Catalyst Preparation}

The metal-boron acid-base bifunctional catalysts were prepared by the sol-gel method, according to the reported procedures with slight modification [21,22]. In a typical synthetic procedure, $1.0 \mathrm{~g}$ polyethylene-polypropylene glycol (F68) was dissolved into $20 \mathrm{~mL}$ absolute ethanol, and kept stirred for $1 \mathrm{~h}$ at $40{ }^{\circ} \mathrm{C}$, followed by addition of $10 \mathrm{mmol}$ metal salt (i.e., $\mathrm{Ca}\left(\mathrm{NO}_{3}\right)_{2} \cdot 4 \mathrm{H}_{2} \mathrm{O}, \mathrm{AlCl}_{3} \cdot 6 \mathrm{H}_{2} \mathrm{O}$, $\mathrm{Mg}\left(\mathrm{NO}_{3}\right)_{2} \cdot 6 \mathrm{H}_{2} \mathrm{O}, \mathrm{Zn}\left(\mathrm{NO}_{3}\right)_{2} \cdot 6 \mathrm{H}_{2} \mathrm{O}$, and $\left.\mathrm{ZrOCl}_{2} \cdot 8 \mathrm{H}_{2} \mathrm{O}\right)$. After stirring at $40{ }^{\circ} \mathrm{C}$ for $1 \mathrm{~h}, 10 \mathrm{mmol} \mathrm{H}_{3} \mathrm{BO}_{3}$ 
was added into the resulting solution and stirred for another $1 \mathrm{~h}$. Upon ultrasonic treatment for $0.5 \mathrm{~h}$, the resulting transparent solution was transferred into a surface dish and placed in an oven $\left(45^{\circ} \mathrm{C}\right)$, where the solvent was slowly evaporated for $24 \mathrm{~h}$ and then dried in an $80^{\circ} \mathrm{C}$ for another $24 \mathrm{~h}$. Finally, the solid product was subjected to calcination at $700{ }^{\circ} \mathrm{C}$ (heating ramp: $5^{\circ} \mathrm{C} / \mathrm{min}$ ) for $6 \mathrm{~h}$ in air to give solid powder.

According to the kind of metal salts (i.e., $\mathrm{Ca}\left(\mathrm{NO}_{3}\right)_{2} \cdot 4 \mathrm{H}_{2} \mathrm{O}, \mathrm{AlCl}_{3} \cdot 6 \mathrm{H}_{2} \mathrm{O}, \mathrm{Mg}\left(\mathrm{NO}_{3}\right)_{2} \cdot 6 \mathrm{H}_{2} \mathrm{O}$, $\mathrm{Zn}\left(\mathrm{NO}_{3}\right)_{2} \cdot 6 \mathrm{H}_{2} \mathrm{O}$, and $\left.\mathrm{ZrOCl}_{2} \cdot 8 \mathrm{H}_{2} \mathrm{O}\right)$, the resulting catalysts were denoted as $\mathrm{Ca}-\mathrm{B}(700), \mathrm{Al}-\mathrm{B}(700)$, $\mathrm{Mg}-\mathrm{B}(700), \mathrm{Zn}-\mathrm{B}(700)$, and $\mathrm{Zr}-\mathrm{B}(700)$, respectively. For comparison, the selected Ca-B catalysts were calcined at different temperatures of $550,600,700$, and $800{ }^{\circ} \mathrm{C}$, which were designated as $\mathrm{Ca}-\mathrm{B}(550)$, Ca-B(600), Ca-B(700), and Ca-B(800), respectively.

\subsection{Catalyst Characterization}

X-ray diffraction (XRD) patterns were recorded with Tongda TD-3500 X-ray diffractometer (Cu $\mathrm{K} \alpha$ radiation $\lambda=0.154056 \mathrm{~nm})$ ) to characterize the crystal form of the samples ( $2 \theta$ angle recorded from 5 to $80^{\circ}$ ). IR spectra were obtained by using KBr 360 Nicolet FT-IR apparatus infrared spectrometer. The mass loss was measured by thermogravimetric analysis (TGA) with temperature of from $25{ }^{\circ} \mathrm{C}-800{ }^{\circ} \mathrm{C}$ in $\mathrm{N}_{2}$ atmosphere (Mettler TGA/DSC1). Acidity and alkalinity of the materials were evaluated by TPD (Micromeritics Auto Chem II 2920 apparatus), He was used as carrier gas, the maximum temperature is $700{ }^{\circ} \mathrm{C}$, and the $\mathrm{NH}_{3} / \mathrm{CO}_{2}$ gas flow rate is $20 \mathrm{~mL} / \mathrm{min}$. The morphology and internal structure of the catalysts were observed by SEM (JSM-6700F, 5 KV) and HR-TEM (JEM-2000FX, $200 \mathrm{kV}$ ). The physical properties (specific surface area, pore volume and pore size) of the catalyst were measured at $77 \mathrm{~K}$ by $\mathrm{N}_{2}$ adsorption-desorption device (Micromeritics Co., Ltd., ASAP 2460). The acid type of the catalyst was determined FT-IR of pyridine adsorption (Nicolet iS50 Thermo sepectrometer). The water contact angle was measured by device of Dataphysics Corporation (OCA15EC, Germany).

\subsection{Biodiesel Production from Jatropha Oil with High Acid Values}

In a general procedure, Jatropha crude oil (1.0 g), absolute methanol (0.65 g), and metal-B catalyst $(0.04 \mathrm{~g})$ were added into a glass pressure bottle $(15 \mathrm{~mL}$, Beijing Synthware Co., Ltd., Beijing, China). The reaction conditions for catalyst selection were performed with 20/1 methanol/oil mole ratio and $4 \mathrm{wt} \%$ catalyst dosage at $85^{\circ} \mathrm{C}$ for $6 \mathrm{~h}$, while the subsequent reaction conditions were performed under the optimized conditions of $20 / 1$ methanol/oil mole ratio and $4 \mathrm{wt} \%$ catalyst dosage at $105^{\circ} \mathrm{C}$ for $2 \mathrm{~h}$. The magnetic stirring speed was $600 \mathrm{rpm}$ in the reaction.

After reaching the specific reaction time, the liquid products were obtained after centrifugation $(10,000 \mathrm{rpm})$ for $5 \mathrm{~min}$ to remove the catalyst. Then petroleum ether was added to the liquid, while the upper layer liquid was separated by vacuum distillation to remove excess methanol. Experiments were repeated for three times, and the results were shown in average values. The yields of biodiesel were detected by nuclear magnetic resonance (NMR, $500 \mathrm{M}, \mathrm{JEOL}$ ) using tetramethylsilane (TMS) as internal reference.

\subsection{Catalyst Reusability}

In order to study the catalyst reusability, the solid catalyst was recycled under optimized reaction conditions (20/1 methanol/oil mole ratio and $4 \mathrm{wt} \%$ catalyst dosage at $105^{\circ} \mathrm{C}$ for $2 \mathrm{~h}$ ), followed by washing with methanol and petroleum ether to remove any impurities. The scrubbed catalyst was calcined at $700{ }^{\circ} \mathrm{C}$ for $6 \mathrm{~h}$, then used for the next cycle. 


\section{Results and Discussions}

\subsection{Catalyst Characterization}

As shown in Figure 1A, the XRD diffraction lines $22.1^{\circ}, 66.2^{\circ}$ a and $\mathrm{B}$ belong to $\mathrm{Al}_{2} \mathrm{O}_{3}[20,21]$. The diffraction lines of $\mathrm{MgO}$ are at $42.9^{\circ}, 62.3^{\circ}$ [22], and $28.2^{\circ}, 30.4^{\circ}, 34.8^{\circ}, 50.4^{\circ}$, and $60.3^{\circ}$ are attributed to the characteristic diffraction lines of $\mathrm{ZrO}_{2}$ [23]. The characteristic diffraction lines of $\mathrm{ZnO}$ appear in $31.8^{\circ}, 34.6^{\circ}, 36.4^{\circ}, 47.7^{\circ}, 56.7^{\circ}, 63.0^{\circ}, 68.1^{\circ}$ [24], and $\mathrm{B}_{2} \mathrm{O}_{3}$ diffraction lines were at $14.2^{\circ}$, $27.6^{\circ}$ [22]. This result proves that the successful preparation of those catalysts (Al-B(700), Mg-B(700), $\mathrm{Zn}-\mathrm{B}(700), \mathrm{Zr}-\mathrm{B}(700)$. The wide XRD diffraction lines of Al-B catalysts illustrate that these materials are more likely to exist in the form of amorphous powders, which can expose active sites and provide more active sites, as proven by the high acid density of Al-B in Table S1.

Regarding the $\mathrm{Ca}-\mathrm{B}$ catalysts calcined at different temperatures, the materials calcined at 550 and $660{ }^{\circ} \mathrm{C}$, as well as those at 700 and $800^{\circ} \mathrm{C}$, had similar structures (Figure 1B). The XRD characteristic diffraction lines of $\mathrm{CaO}$ are $32.3^{\circ}, 37.4^{\circ}$, and $54.1^{\circ}$ in the $\mathrm{Ca}-\mathrm{B}$ catalyst, indicating that the catalyst alkalinity may come from $\mathrm{CaO}$ [25-29]. The diffraction lines at $18.2^{\circ}$ and $34.2^{\circ}$ indicate the existence of $\mathrm{Ca}(\mathrm{OH})_{2}$ in a certain amount, which could be due to the water absorption of $\mathrm{CaO}$. The characteristic diffraction lines of $\mathrm{CaCO}_{3}$ appeared in $23.4^{\circ}, 36.2^{\circ}$, and $39.3^{\circ}$, which may be formed by the reaction of $\mathrm{CaO}$ and $\mathrm{CO}_{2}$ during calcination [30]. The diffraction line at $27.9^{\circ}$ showed the presence of $\mathrm{B}_{2} \mathrm{O}_{3}$ [23].

The absorption bands of $\mathrm{CaO}, \mathrm{Ca}(\mathrm{OH})_{2}$ and $\mathrm{CaCO}_{3}$ were observed in FT-IR spectra (Figure $1 \mathrm{C}$ ). The absorption bands 869 and $1442 \mathrm{~cm}^{-1}$ belong to $\mathrm{CaCO}_{3}$, while $3640 \mathrm{~cm}^{-1}$ is the characteristic absorption band of $\mathrm{OH}$ group for $\mathrm{Ca}(\mathrm{OH})_{2}$. The Ca-B catalysts calcined at 700 and $800{ }^{\circ} \mathrm{C}$ were weaker, showing the small amount of these species, which could be supported by a previous report [30-32]. In addition, the absorption band at $527 \mathrm{~cm}^{-1}$ confirmed the existence of $\mathrm{CaO}$, which is consistent with the characterization result of XRD.
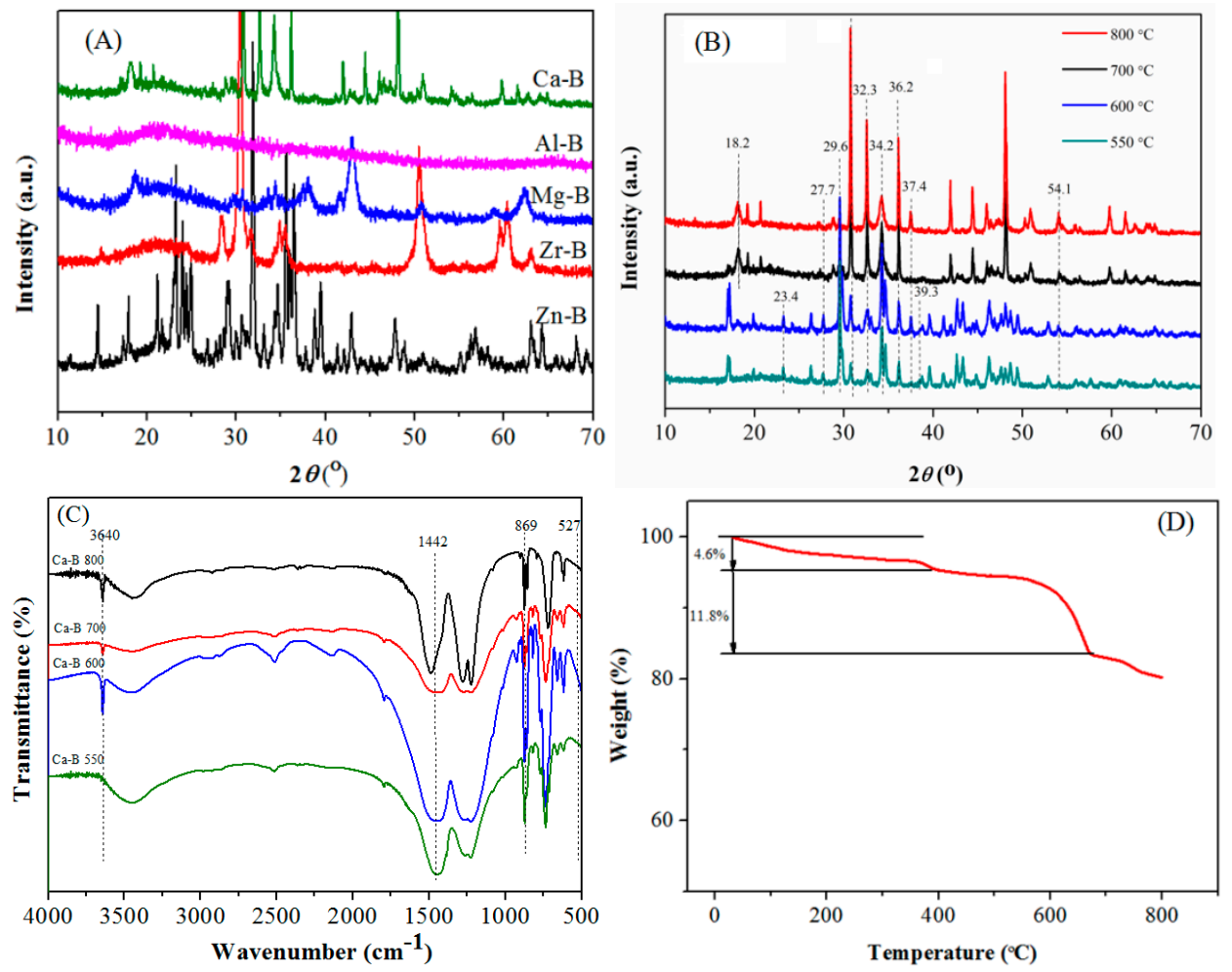

Figure 1. (A) $\mathrm{XRD}$ patterns of different catalysts $\left(\mathrm{CaO}, \mathrm{Al}_{2} \mathrm{O}_{3}, \mathrm{MgO}, \mathrm{ZnO}, \mathrm{ZrO}_{2}\right.$, and $\left.\mathrm{B}_{2} \mathrm{O}_{3}\right)$; (B) XRD patterns of Ca-B catalysts calcined at $550-800{ }^{\circ} \mathrm{C}$; (C) FT-IR spectra of Ca-B catalysts calcined at 550-800 ${ }^{\circ} \mathrm{C}$; (D) Thermogravimetric (TG) curve of Ca-B(700) catalyst. 
Thermogravimetric (TG) analysis showed that the Ca-B(700) catalyst had good stability (Figure 1D). The mass loss was only $4.6 \%$ when the temperature was lower than $383{ }^{\circ} \mathrm{C}$, which is possibly due to the removal of water adsorbed in the sample and the decomposition of a small amount of residual organic matters. In addition, owing to the strong hygroscopicity of $\mathrm{B}_{2} \mathrm{O}_{3}$, the removal of crystalline water will also result in the mass loss $[30,33]$. When the temperature was in the range of 383 to $677^{\circ} \mathrm{C}$, the mass loss of $11.8 \%$ was observed, which is mainly caused by the decomposition of $\mathrm{Ca}(\mathrm{OH})_{2}[31]$.

$\mathrm{N}_{2}$ adsorption-desorption tests show that the specific surface area and pore volume of Ca-B materials increase with the increase of calcination temperature (Table 1), which may be conducive to the (trans)esterification reaction. The specific surface area was found to increase with the increase of the calcination temperature, and the specific surface area of $\mathrm{Ca}-\mathrm{B}(700)$ was $4.72 \mathrm{~m}^{2} / \mathrm{g}$. The pore size increased, then decreased, with the increase of calcination temperature, all of which were larger than $3.5 \mathrm{~nm}$, which is beneficial to the mass transfer of triglyceride [34,35]. These results can be explained by the complete removal of organic template to generate additional pores and the enhanced stability in the presence of $\mathrm{B}$ at the relatively high calcination temperatures. The acid and base densities of the Ca-B catalysts calcined at different temperatures were determined by $\mathrm{NH}_{3} / \mathrm{CO}_{2}-\mathrm{TPD}$, respectively. The Ca-B(700) catalyst exhibited the highest acid $(2.68 \mathrm{mmol} / \mathrm{g})$ and base $(1.89 \mathrm{mmol} / \mathrm{g})$ capacity. $\mathrm{Ca}-\mathrm{B}(700)$ seems to be a promising catalyst for the production of biodiesel.

Table 1. Textural properties of different Ca-B materials.

\begin{tabular}{cccccc}
\hline Sample & $\begin{array}{c}\mathbf{S}_{\text {BET }} \\
\left(\mathbf{m}^{\mathbf{2}} / \mathbf{g}\right)\end{array}$ & $\begin{array}{c}\text { Pore Volume } \\
\left(\mathbf{c m}^{\mathbf{3}} \mathbf{g} \mathbf{)}\right.\end{array}$ & $\begin{array}{c}\text { Pore Diameter } \\
\mathbf{( n m )}\end{array}$ & $\begin{array}{c}\text { Acid Density } \\
\left(\mathbf{m m o l} \cdot \mathbf{g}^{\mathbf{1}} \mathbf{)}\right.\end{array}$ & $\begin{array}{c}\text { Base Density } \\
\left(\mathbf{m m o l} \cdot \mathbf{g}^{-\mathbf{1}} \mathbf{)}\right.\end{array}$ \\
\hline Ca-B (550) & 2.02 & 0.0081 & 16.0 & 0.21 & 0.17 \\
Ca-B (600) & 2.01 & 0.011 & 21.4 & 0.63 & 0.41 \\
Ca-B (700) & 4.72 & 0.022 & 19.0 & 2.68 & 1.89 \\
Ca-B (800) & 5.86 & 0.024 & 16.6 & 2.67 & 1.69 \\
\hline
\end{tabular}

As can be seen from the SEM image (Figure 2A), the morphology of Ca-B(700) presents a smooth and uniform rod-like structure. The average length of the rod catalyst was estimated to be about $150 \mathrm{~nm}$. The smooth morphology of the rod-like catalyst makes the active sites to be more dispersed, ensuring better contact with the substrate to speed up the reaction rate. The image of TEM shows that $\mathrm{Ca}-\mathrm{B}(700)$ material has mesoporous structure (Figure 2B), which facilitates not only the entry of substrate into the pores, but also the product departure. In addition, the elemental mapping diagram shows that $\mathrm{Ca}, \mathrm{O}$, and $\mathrm{B}$ elements are uniformly distributed in the catalyst (Figure 2C), indicating that the preparation of the catalyst was successful, which is mainly attributed to the homogeneous doping of the catalyst at the micro-level by the gel-sol method. Furthermore, high resolution (HR)-TEM image further reveals the presence of $\mathrm{CaO}$ crystal planes in $\mathrm{Ca}-\mathrm{B}(700)$ (Figure 2D), which is in agreement with the previous result [36].

Compared with other catalysts (Figures S1 and S2, Tables 1 and 2), $\mathrm{Ca}-\mathrm{B}(700)$ has smaller average particle size and is more dispersed without agglomeration. Moreover, $\mathrm{Ca}-\mathrm{B}(700)$ has more regular rod-like morphology, suitable mesoporous diameter, and higher acid/base density. In this respect, $\mathrm{Ca}-\mathrm{B}(700)$ exhibits the great potential as acid-base bifunctional catalyst with excellent performance in biodiesel production. 

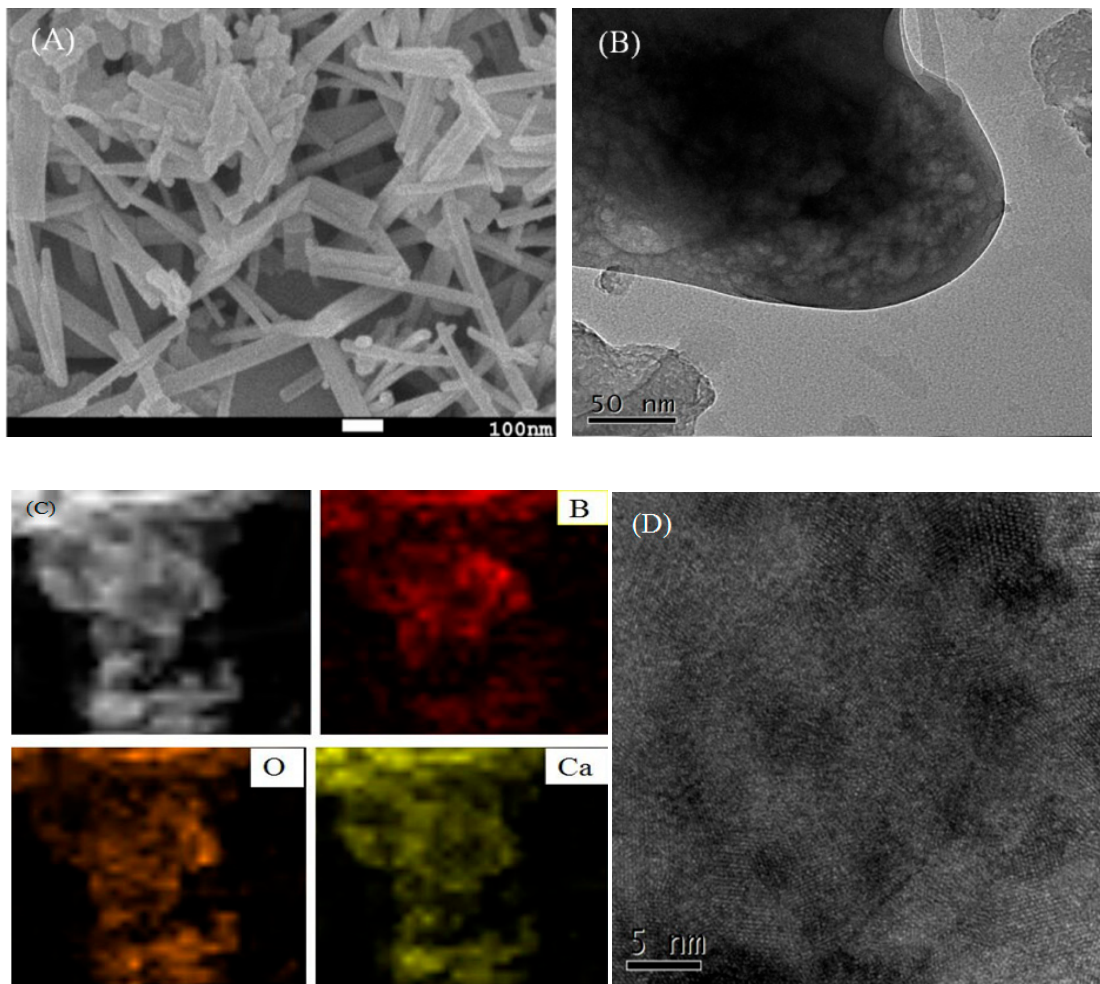

Figure 2. (A) SEM image, (B) TEM image, (C) Elemental mapping, and (D) HR-TEM image of Ca-B(700).

Table 2. Comparison of structural characteristics of different catalysts.

\begin{tabular}{|c|c|c|c|c|c|c|c|}
\hline Sample & $\begin{array}{c}\mathrm{S}_{\mathrm{BET}} \\
\left(\mathrm{m}^{2} / \mathrm{g}\right)\end{array}$ & $\begin{array}{c}\text { Pore } \\
\text { Volume } \\
\left(\mathrm{cm}^{3} / \mathrm{g}\right)\end{array}$ & $\begin{array}{c}\text { Pore } \\
\text { Diameter } \\
(\mathrm{nm})\end{array}$ & $\begin{array}{l}\text { Acid Density } \\
\left(\mathrm{mmol} \cdot \mathrm{g}^{-1}\right)\end{array}$ & $\begin{array}{l}\text { Base Density } \\
\left(\mathrm{mmol}^{\left.-\mathrm{g}^{-1}\right)}\right.\end{array}$ & Morphology & Ref. \\
\hline $\mathrm{CaO}-\mathrm{La}_{2} \mathrm{O}_{3}$ & 7.73 & - & - & 0.28 & 3.20 & Agglomeration & [14] \\
\hline Chicken-eggshell & 54.6 & 0.015 & 0.54 & - & 0.21 & Irregular & [37] \\
\hline Hydrated-lime & 15.0 & 0.21 & - & - & 0.33 & Aggregation & [38] \\
\hline $30 \% \mathrm{CaO}-\mathrm{CeO}_{2} / \mathrm{HAP}-650$ & 13.5 & 0.019 & - & - & 0.45 & Regular blocks & [39] \\
\hline $\mathrm{Ca}-\mathrm{B}(700)$ & 4.72 & 0.022 & 19.0 & 2.68 & 1.89 & Rod-like & This work \\
\hline
\end{tabular}

The acidity of $\mathrm{Ca}-\mathrm{B}(700)$ was examined by the pyridine-adsorbed FT-IR at $200{ }^{\circ} \mathrm{C}$ (Figure S3). The absorption band at $1446 \mathrm{~cm}^{-1}$ is attributed to the presence of Lewis (L) acid sites, while the absorption band at $1487 \mathrm{~cm}^{-1}$ should be Brønsted (B) acid and Lewis (L) acid sites. In addition, the absorption band at $1597 \mathrm{~cm}^{-1}$ is assigned to the adsorption of pyridine [23,40,41]. In addition, the contact angle of the $\mathrm{Ca}-\mathrm{B}(700)$ catalyst was tested and found to be $71.1^{\circ}$ (Figure S4), showing expectable hydrophobicity. This contact angle can basically meet the hydrophobic requirements of catalysts in biodiesel preparation.

Figure S5 shows that there is no obvious correlation between the specific surface area, pore volume, pore size, and biodiesel yield of different catalysts. In turn, acid-base properties of the catalysts are the main factors affecting the catalytic performance. Moreover, the average sizes of microcrystals have been evaluated using the XRD method by Scherrer Equation (1), and the obtained average sizes of microcrystals plotted with biodiesel yield are shown in Figure S6. It was found that the yield of biodiesel increased gradually with the decrease of crystal size of Ca-B catalyst, and a maximum biodiesel yield was obtained in the case of $\mathrm{Ca}-\mathrm{B}(700)$. However, further decease in crystal size resulted in the decline of biodiesel yield for $\mathrm{Ca}-\mathrm{B}(800)$. These results indicate that the catalyst crystal size affects the biodiesel yield, to a certain extent. 


\subsection{Biodiesel Yield Analysis}

NMR technology is a convenient and effective method to detect the yields of biodiesel [42-44]. In the process of NMR detection, $\mathrm{CDCl}_{3}$ is usually used as solvent with TMS as internal standard. The calculation is mainly based on the difference in the displacement of hydrogen peaks in the substrate/product before and after transesterification. Specifically, there is no peak at $3.66 \mathrm{ppm}$ before the reaction, while a new single peak turns out at $3.66 \mathrm{ppm}$ upon completion of the reaction (Figure 3), which belongs to the methoxy species obtained by transesterification of methanol. The proton peak belonging to $\alpha-\mathrm{CH}_{2}$ appears at $2.30 \mathrm{ppm}$, showing a perfect three-fold peak. The glycerol peak in 4.0-4.2 ppm disappeared after the reaction. This is undoubtedly quantitative for biodiesel.

$$
\mathrm{C}=100 \times\left(2 \mathrm{~A}_{\mathrm{Me}} / 3 \mathrm{~A}_{\mathrm{CH} 2}\right)
$$

$\mathrm{A}_{\mathrm{Me}}$ indicates the integral area of methoxy hydrogen at $3.66 \mathrm{ppm}$, while $\mathrm{A}_{\mathrm{CH} 2}$ refers to the protons integral area of $\alpha-\mathrm{CH}_{2}$ at $2.30 \mathrm{ppm}$.
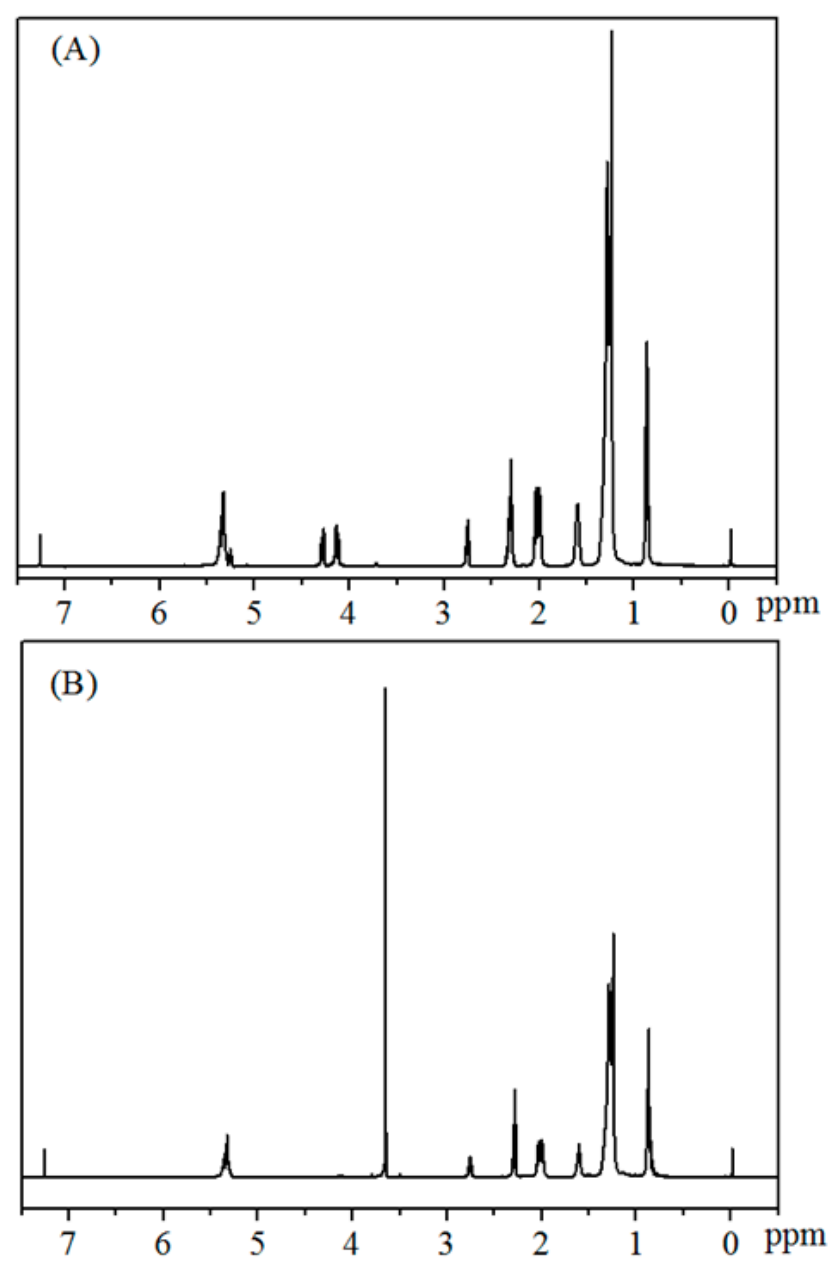

Figure 3. ${ }^{1} \mathrm{H}$ NMR spectra of the reaction mixtures for biodiesel production from (A) Jatropha oil, and (B) biodiesel.

\subsection{Biodiesel Production from Jatropha Oil with High Acid Value}

The catalytic activity of different materials for biodiesel production is shown in Figure 4A. It can be seen that there was almost no reaction without catalyst, and the biodiesel yields of various metal-B catalysts (Al-B, Mg-B, Zr-B, Zn-B) calcined at $700{ }^{\circ} \mathrm{C}$ were all less than $20 \%$ at $85{ }^{\circ} \mathrm{C}$ for $6 \mathrm{~h}$. In contrast, the $\mathrm{Ca}-\mathrm{B}$ catalyst had excellent catalytic activity, with a high biodiesel yield of $94 \%$ under identical 
reaction conditions. These results indicate that the alkalinity of the catalyst plays a promotional role in the superior biodiesel yield at a relatively mild reaction temperature of $85^{\circ} \mathrm{C}$.

The effect of calcined Ca-B catalysts at different temperatures on the biodiesel yield of the reaction was further explored. It can be seen from Figure 4B, the catalytic activity increased with the increase of calcination temperature from $550-700{ }^{\circ} \mathrm{C}$, but began to decrease as the calcination temperature reached $800{ }^{\circ} \mathrm{C}$. These results further illustrate the crucial role of the catalyst acidity and basicity, where $\mathrm{Ca}-\mathrm{B}(700)$ with the highest acidity and basicity afforded the best biodiesel yield.
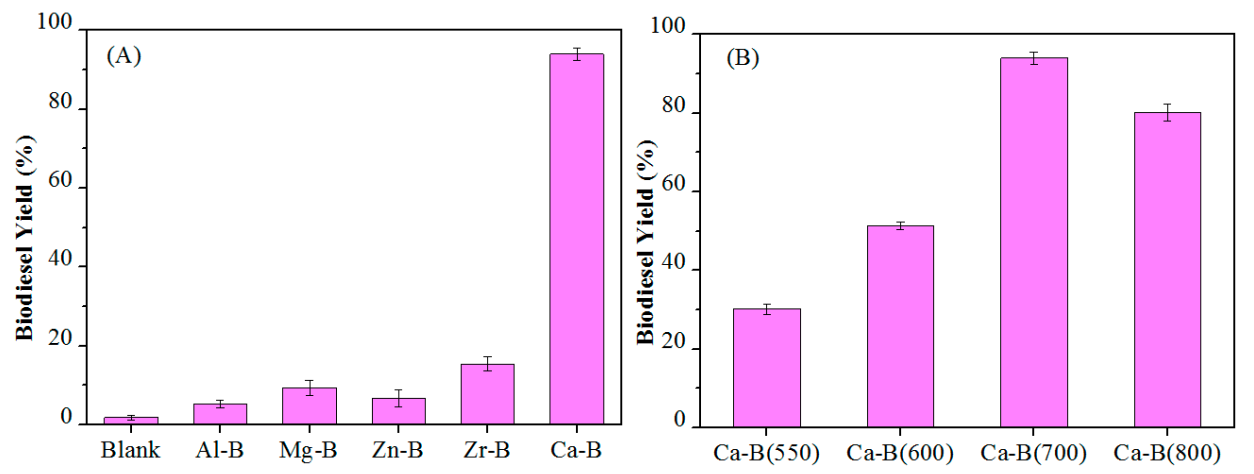

Figure 4. (A) Activity of different metal-B catalysts calcined at $700{ }^{\circ} \mathrm{C}$ in biodiesel production, and (B) Effect of calcination temperature for Ca-B catalysts on the biodiesel production. Reaction conditions: $2.0 \mathrm{~g}$ oil, $1.30 \mathrm{~g}$ methanol, $0.12 \mathrm{~g}$ catalyst, $\mathrm{T}=85^{\circ} \mathrm{C}, \mathrm{t}=6 \mathrm{~h}$.

\subsection{Optimization of Reaction Parameters}

Reaction conditions have a great influence on the production cost in industrial applications. Therefore, optimizing reaction conditions is very important in the preparation of biodiesel. The reaction temperature $\left(85-125^{\circ} \mathrm{C}\right)$, reaction time $(1-5 \mathrm{~h})$, amount of catalyst $(1-5 \mathrm{wt} \%)$, and molar ratio of $\mathrm{MeOH}$ to oil (5:1-25:1) were optimized by single factor experiments.

\subsubsection{Reaction Temperature}

The temperature is the most important factor affecting the reaction, so the temperature was first optimized with 20/1 methanol/oil molar ratio and $4 \mathrm{wt} \% \mathrm{Ca}-\mathrm{B}(700)$ after $2 \mathrm{~h}$. It can be seen from Figure 5A that as the temperature increased, the yield of biodiesel increased accordingly. The biodiesel yield was found to be $80.1 \%$ and $99.3 \%$ at $85{ }^{\circ} \mathrm{C}$ and $125^{\circ} \mathrm{C}$, respectively, while a good yield of $95.3 \%$ could be obtained at $105^{\circ} \mathrm{C}$. Therefore, the temperature of $105^{\circ} \mathrm{C}$ is selected as the suitable temperature for the production of biodiesel with high acid value raw materials.

\subsubsection{Reaction Time}

Since the esterification and transesterification of the one-pot process for biodiesel production are reversible reactions, the choice of short reaction time is very advantageous for decreasing the production cost. The yields of biodiesel were $78.3 \%$ and $96.7 \%$ after 1 and $2 \mathrm{~h}$, respectively (Figure 5B). Then, the yield decreased slightly with prolonging the reaction time, and a slight decline in biodiesel yield of $94.0 \%$ was observed as the reaction time was $5 \mathrm{~h}$. Therefore, it is suitable to use $2 \mathrm{~h}$ as the optimal reaction time to get the best biodiesel yield.

\subsubsection{Methanol/Oil Molar Ratio}

The molar ratio of $\mathrm{MeOH}$ to oil is also an important parameter in biodiesel production, which determines the used amount of methanol and thus affects the production cost. As shown in Figure 5C, when the molar ratio of $\mathrm{MeOH}$ to oil was 5:1, the yield of biodiesel was $76.0 \%$. With the molar ratio of alcohol to oil increasing to $20: 1$, the yield rose to $95.3 \%$. As the molar ratio of alcohol to oil was further 
increased to $25: 1$, the yield was $97.3 \%$. From above discussions, 20:1 alcohol-oil ratio is a better choice, which not only achieves the expected yield, but also well controls the production cost.

\subsubsection{Catalyst Dosage}

Use of a catalyst can accelerate the reaction rate, and the ideal state is to achieve the best catalytic effect with a minimum of the catalyst. The effect of the catalyst amount from $1 \%$ to $5 \%$, relative to the weight of the substrate (Jatropha oil) on the biodiesel yield, was investigated under the reaction conditions of $105^{\circ} \mathrm{C}, 4 \mathrm{~h}$, and the molar ratio of alcohol to oil is 20:1. It can be observed (Figure 5D) that the yield sharply increased from 24.1 to $96.0 \%$ as the catalyst amount increased from 1 to $4 \mathrm{wt} \%$, while the yield slightly increased from 95.3 to $96.0 \%$ as the catalyst dosage was arisen from 4 to $5 \mathrm{wt} \%$. Therefore, a catalyst amount of $4 \%$ by weight is optimal for the reaction.
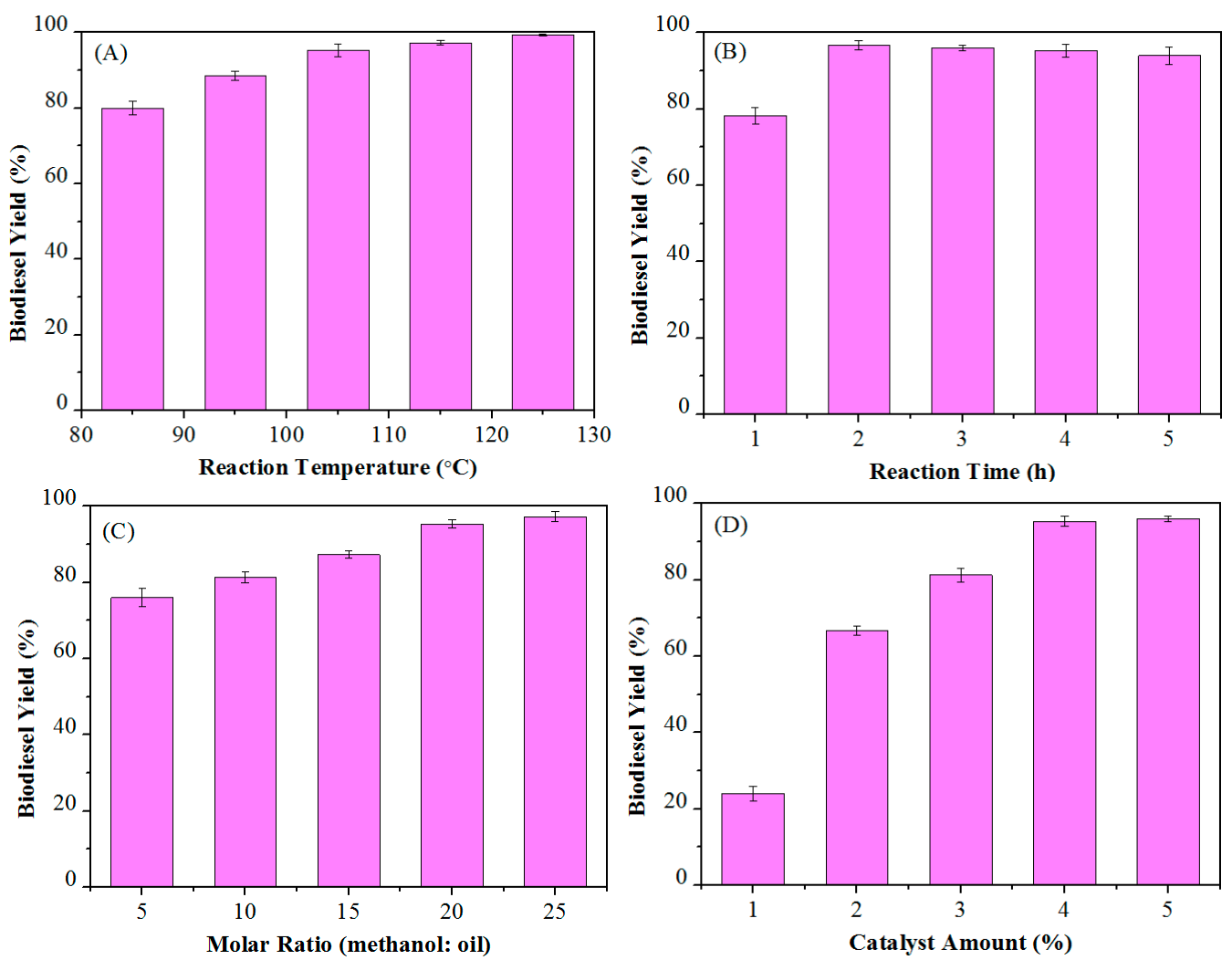

Figure 5. Single-factor optimization of biodiesel production from Jatropha oil (acid value: $6.75 \mathrm{mg} \mathrm{KOH} / \mathrm{g}$ ) catalyzed by the Ca-B(700) catalyst: (A) reaction temperature, $(\mathbf{B})$ reaction time, $(\mathbf{C})$ methanol/oil molar ratio, and (D) catalyst dosage.

\subsection{Catalyst Reusability}

The multiple reuse of a catalyst can reduce the production cost, which is very favorable for industrial production of biodiesel. Therefore, the reusability of the catalyst was tested under the optimized conditions of methanol/oil molar ratio 20/1, $4 \mathrm{wt} \% \mathrm{Ca}-\mathrm{B}(700), 105{ }^{\circ} \mathrm{C}$ for $2 \mathrm{~h}$. After each cycle of the reaction, the centrifuged catalyst was washed with petroleum ether. By comparing the XRD patterns of $\mathrm{Ca}-\mathrm{B}(700)$ catalyst before and after the reaction (Figure $6 \mathrm{~A}$ ), it was observed that the main diffraction lines did not evidently change, indicating that the catalyst was stable and its crystal morphology remained during the consecutive reaction cycles. However, it was shown that the adhering biodiesel and triglyceride could not be washed cleanly from the catalyst, which made the active sites of the catalyst covered (Figure 6B). The infrared spectra of the catalysts after the reaction that the absorption bands of 2846 and $2920 \mathrm{~cm}^{-1}$ indicate the existence of a long chain alkyl groups. After calcination of the recovered catalyst at $700{ }^{\circ} \mathrm{C}$ for $6 \mathrm{~h}$ to remove the residue attached to the surface, 
the yield of biodiesel was still more than $90 \%$ in five consecutive reaction cycles (Figure 6C), indicating that the catalyst had good reusability and stability. Thermal filtration experiment is an important method to test whether the solid catalyst exhibits homogeneous or heterogeneous behavior [45,46]. The Ca-B(700) catalyst proved to be a heterogeneously recyclable catalyst for biodiesel production by thermal filtration experiment (Figure 6D). These results indicate that $\mathrm{Ca}-\mathrm{B}(700)$ with robust structure and good stability is a promising catalyst for biodiesel production.
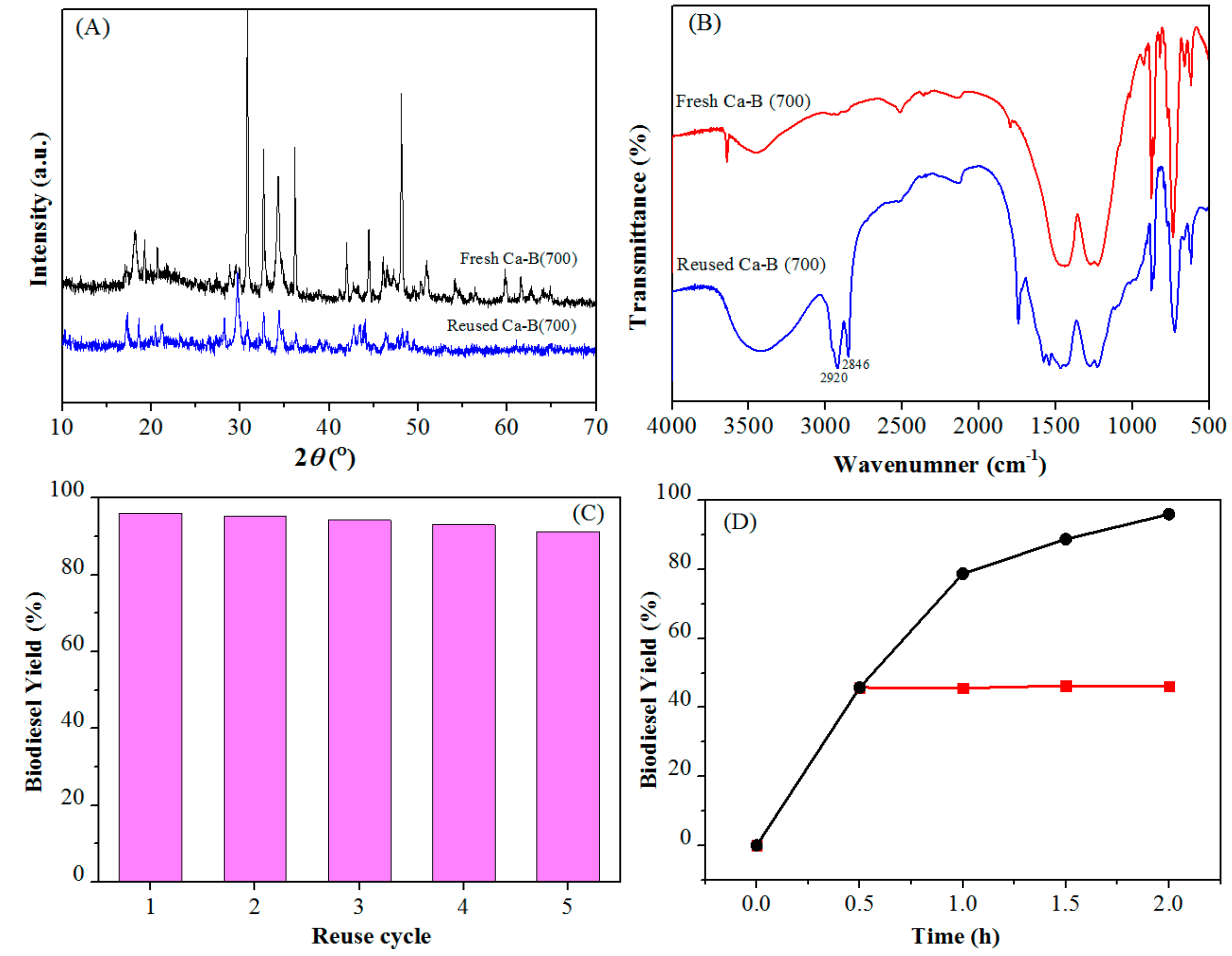

Figure 6. (A) XRD, (B) FT-IR spectra of Ca-B(700) before and after the reaction, (C) Reusability of the $\mathrm{Ca}-\mathrm{B}(700)$ catalyst in biodiesel production. Reaction conditions: ethanol/oil molar ratio $20 / 1,4 \mathrm{wt} \%$ $\mathrm{Ca}-\mathrm{B}(700), 105{ }^{\circ} \mathrm{C}$ for $2 \mathrm{~h}$, (D) Hot filtration test of $\mathrm{Ca}-\mathrm{B}(700)$ at $105{ }^{\circ} \mathrm{C}$.

It can be seen from Table 3 that $\mathrm{Ca}-\mathrm{B}(700)$ is an excellent catalyst. It has relatively mild reaction temperature, good stability, and reusability. At the same time, it has excellent catalytic performance for the synthesis of biodiesel from raw materials with high acid values.

Table 3. Comparison of the performance of different heterogeneous catalysts.

\begin{tabular}{|c|c|c|c|c|c|}
\hline NO. & Catalyst & Feedstock & Reaction Conditions & $\begin{array}{l}\text { Biodiesel Yield } \\
\text { (Conversion) (\%) }\end{array}$ & Ref. \\
\hline 1 & Zn $8 @$ Fe-C 400 & Jatropha oil & $\begin{array}{c}\mathrm{T}=160^{\circ} \mathrm{C}, \mathrm{CA}=7 \mathrm{wt} \% \\
\mathrm{M} / \mathrm{O}=40: 1, \mathrm{t}=4 \mathrm{~h}\end{array}$ & 100 & [3] \\
\hline 2 & FS-B-L-IL & K. integrifoliola oil & $\begin{array}{c}\mathrm{T}=160{ }^{\circ} \mathrm{C}, \mathrm{CA}=10 \mathrm{wt} \%, \\
\mathrm{M} / \mathrm{O}=20: 1, \mathrm{t}=3 \mathrm{~h}\end{array}$ & 93.7 & [6] \\
\hline 3 & K-ITQ-6 & $\begin{array}{l}\text { triglycerides FFAs } \\
\text { content } 5.58 \%\end{array}$ & $\begin{array}{c}\mathrm{T}=180{ }^{\circ} \mathrm{C}, \mathrm{CA}=5 \mathrm{wt} \% \\
\mathrm{M} / \mathrm{O}=20: 1, \mathrm{t}=24 \mathrm{~h}\end{array}$ & 97 & [13] \\
\hline 4 & $\mathrm{CaO}-\mathrm{La}_{2} \mathrm{O}_{3}$ & Jatropha oil & $\begin{array}{c}\mathrm{T}=160^{\circ} \mathrm{C}, \mathrm{CA}=3 \mathrm{wt} \% \\
\mathrm{M} / \mathrm{O}=25: 1, \mathrm{t}=3 \mathrm{~h}\end{array}$ & 98.76 & {$[14]$} \\
\hline 5 & $\mathrm{Ca}-\mathrm{B}(700)$ & $\begin{array}{c}\text { Firmiana } \\
\text { platanifolia oil }\end{array}$ & $\begin{array}{c}\mathrm{T}=65^{\circ} \mathrm{C}, \mathrm{CA}=4 \mathrm{wt} \% \\
\mathrm{M} / \mathrm{O}=20: 1, \mathrm{t}=2 \mathrm{~h}\end{array}$ & 98.5 & This study \\
\hline 6 & $\mathrm{Ca}-\mathrm{B}(700)$ & Jatropha oil & $\begin{array}{c}\mathrm{T}=105^{\circ} \mathrm{C}, \mathrm{CA}=4 \mathrm{wt} \% \\
\mathrm{M} / \mathrm{O}=20: 1, \mathrm{t}=2 \mathrm{~h}\end{array}$ & 96.0 & This study \\
\hline
\end{tabular}

$\mathrm{CA}$ - catalyst amount; $\mathrm{T}$-reaction temperature; $\mathrm{M} / \mathrm{O}$ - methanol to oil molar ratio; $\mathrm{t}$-reaction time. 


\subsection{Biodiesel Production from Firmiana Platanifolia L.f. Oil with Low Acid Value}

Delighted by the fact that $\mathrm{Ca}-\mathrm{B}(700)$ can efficiently catalyze the production of biodiesel from Jatropha oil, the biodiesel production from Firmiana platanifolia L.f. with a low acid value $(0.8 \mathrm{KOH}$ $\mathrm{mg} / \mathrm{g}$ ) oil was also tested under the reaction conditions of $4 \mathrm{wt} \%$ catalyst dosage, 20:1 molar ratio of $\mathrm{MeOH}$ to oil, and reaction temperature of $65-105^{\circ} \mathrm{C}$ for reaction time of $2 \mathrm{~h}$. As can be seen from Figure 7 , the yield of $98.5 \%$ was able to be obtained at a relatively low reaction temperature of $65{ }^{\circ} \mathrm{C}$, which is very beneficial to the production cost control in the practical process. The results show that Ca-B(700) has a good catalytic performance in the preparation of biodiesel from nonedible oils with either high or low acid value.

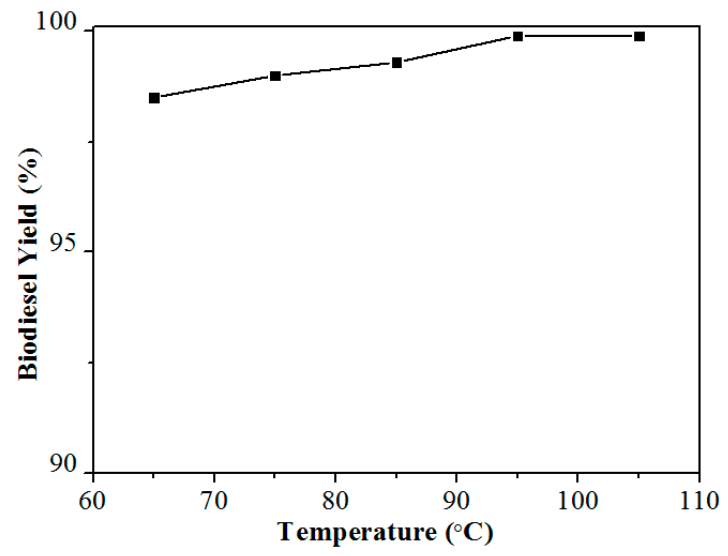

Figure 7. Biodiesel yields obtained from Firmiana platanifolia L.f. oil catalyzed by Ca-B(700) at different temperatures of $65-105^{\circ} \mathrm{C}$. Reaction conditions: Catalyst dosage $4 \mathrm{wt} \%$, the molar ratio of alcohol to oil 20:1, and the reaction time of $2 \mathrm{~h}$.

\section{Conclusions}

In summary, a novel and robust acid-base bifunctional $\mathrm{Ca}-\mathrm{B}(700)$ catalytic material was successfully prepared by the sol-gel method. $\mathrm{Ca}-\mathrm{B}(700)$ was found to show smooth rod-like structure, suitable surface area, uniform pore size, and high acid-base density (acid capacity $2.68 \mathrm{mmol} / \mathrm{g}$, base capacity $1.89 \mathrm{mmol} / \mathrm{g}$ ). Under optimized reaction conditions of 20/1 methanol/oil mole ratio and $4 \mathrm{wt} \%$ catalyst dosage at $105{ }^{\circ} \mathrm{C}$ for $2 \mathrm{~h}$, the yield of biodiesel produced from Jatropha oil with high acid value was as high as $96 \%$. Furthermore, the yield of biodiesel obtained from Firmiana platanifolia L.f. oil was up to $98.5 \%$ at $65{ }^{\circ} \mathrm{C}$ after $2 \mathrm{~h}$. In addition, the Ca-B(700) catalyst had good stability and reusability, which could be recycled for at least five times with little decrease in its activity.

Supplementary Materials: The following are available online at http:/ /www.mdpi.com/1996-1944/12/1/83/s1, Figure S1: SEM images of (A) Al-B(700), (B) Mg-B(700), (C) Zn-B(700), and (D) Zr-B(700); Figure S2: SEM images of (A) Ca-B(550), (B) Ca-B(600), and (C) Ca-B(800); Figure S3: Pyridine-adsorbed IR spectrum of Ca-B(700) catalyst; Figure S4: Hydrophobicity of the catalyst surface of Ca-B(700); Figure S5: Influence of specific surface area (A), pore volume (B), pore size (C) to biodiesel yield of different catalysts; Figure S6: Influence of mean size with different Ca-B catalysts on the production of biodiesel, Table S1: Textural properties of different Materials.

Author Contributions: Conceptualization, H.L.; Methodology, A.W. and H.L.; Investigation, A.W., H.Z. and H.P.; Writing-Original Draft Preparation, A.W.; Writing-Review and Editing, H.L. and S.Y; Supervision, S.Y.; Project Administration, H.L. and S.Y; Funding Acquisition, H.L. and S.Y.

Funding: This study was financially supported by the National Natural Science Foundation of China (21576059 \& 21666008), Fok Ying-Tong Education Foundation (161030), Key Technologies R\&D Program of China (2014BAD23B01), and Guizhou Science \& Technology Foundation ([2018]1037 \& [2017]5788).

Conflicts of Interest: The authors declare no conflict of interest. 


\section{References}

1. Luque, R.; Lovett, J.C.; Datta, B.; Clancy, J.; Campelo, J.M.; Romero, A.A. Biodiesel as feasible petrol fuel replacement: A multidisciplinary overview. Energy Environ. Sci. 2010, 3, 1706-1721. [CrossRef]

2. Li, H.; Yang, T.; Fang, Z. Biomass-derived mesoporous Hf-containing hybrid for efficient MeerweinPonndorf-Verley reduction at low temperatures. Appl. Catal. B Environ. 2018, 227, 79-89. [CrossRef]

3. Wang, Y.T.; Fang, Z.; Yang, X.X.; Yang, Y.T.; Luo, J.; Xu, K.; Bao, G.R. One-step production of biodiesel from Jatropha oils with high acid value at low temperature by magnetic acid-base amphoteric nanoparticles. Chem. Eng. J. 2018, 348, 929-939. [CrossRef]

4. Lin, C.Y.; Lin, H.; Hung, L.B. Fuel structure and properties of biodiesel produced by the peroxidation process. Fuel 2006, 85, 1743-1749. [CrossRef]

5. Wang, R.; Hanna, M.A.; Zhou, W.W.; Bhadury, P.S.; Chen, Q.; Song, B.A.; Yang, S. Production and selected fuel properties of biodiesel from promising non-edible oils: Euphorbia lathyris L., Sapiumsebiferum L. and Jatropha curcas L. Bioresour. Technol. 2011, 102, 1194-1199. [CrossRef] [PubMed]

6. Zhang, H.; Li, H.; Pan, H.; Wang, A.P.; Souzanchi, S.; Xu, C.C.; Yang, S. Magnetically recyclable acidic polymeric ionic liquids decorated with hydrophobic regulators as highly efficient and stable catalysts for biodiesel production. Appl. Energy 2018, 223, 416-429. [CrossRef]

7. Zhang, H.; Zhou, Q.; Chang, F.; Pan, H.; Liu, X.F.; Li, H.; Hu, D.Y.; Yang, S. Production and fuel properties of biodiesel from Firmiana platanifolia L.f. as a potential non-food oil source. Ind. Crop. Prod. 2015, 76, 768-771. [CrossRef]

8. Chang, F.; Hanna, M.A.; Zhang, D.J.; Li, H.; Zhou, Q.; Song, B.A.; Yang, S. Production of biodiesel from non-edible herbaceous vegetable oil: Xanthium sibiricum Patr. Bioresour. Technol. 2013, 140, 435-438. [CrossRef]

9. Zhang, H.; Li, H.; Pan, H.; Liu, X.; Yang, K.; Huang, S.; Yang, S. Efficient production of biodiesel with promising fuel properties from Koelreuteria integrifoliola oil using a magnetically recyclable acidic ionic liquid. Energy Convers. Manag. 2017, 138, 45-53. [CrossRef]

10. Wang, A.P.; Li, H.; Pan, H.; Zhang, H.; Xu, F.; Yu, Z.; Yang, S. Efficient and green production of biodiesel catalyzed by recyclable biomass-derived magnetic acids. Fuel Process. Technol. 2018, 181, 259-267. [CrossRef]

11. Ma, G.; Dai, L.; Liu, D.; Du, W. A robust two-step process for the efficient conversion of acidic soybean oil for biodiesel production. Catalysts 2018, 8, 527. [CrossRef]

12. Huang, M.; Luo, J.; Fang, Z.; Li, H. Biodiesel production catalyzed by highly acidic carbonaceous catalysts synthesized via carbonizing lignin in sub- and super-critical ethanol. Appl. Catal. B Environ. 2016, 190, 103-114. [CrossRef]

13. Macario, A.; Giordano, G.; Onida, B.; Cocina, D.; Tagarelli, A.; Giuffrè, A.M. Biodiesel production process by homogeneous/heterogeneous catalytic system using an acid-base catalyst. Appl. Catal. A Gen. 2010, 378, 160-168. [CrossRef]

14. Lee, H.V.; Juan, J.C.; Taufiq-Yap, Y.H. Preparation and application of binary acid-base CaO- $\mathrm{La}_{2} \mathrm{O}_{3}$ catalyst for biodiesel production. Renew. Energy 2015, 74, 124-132. [CrossRef]

15. Zhou, Q.; Zhang, H.; Chang, F.; Li, H.; Pan, H.; Xue, W.; Hu, D.Y.; Yang, S. Nano $\mathrm{La}_{2} \mathrm{O}_{3}$ as a heterogeneous catalyst for biodiesel synthesis by transesterification of Jatropha curcas L. oil. J. Ind. Eng. Chem. 2015, 31, 385-392. [CrossRef]

16. Li, H.; Fang, Z.; He, J.; Yang, S. Orderly layered Zr-benzylphosphonate nanohybrids for efficient acid/base-mediated bifunctional/cascade catalysis. ChemSusChem 2017, 10, 681-686. [CrossRef]

17. Jo, J.W.; Kim, J.; Kim, K.T.; Kang, J.G.; Kim, M.G.; Kim, K.H.; Ko, H.; Kim, Y.H.; Park, S.K. Highly stable and imperceptible electronics utilizing photoactivated heterogeneous sol-gel metal-oxide dielectrics and semiconductors. Adv. Mater. 2015, 27, 1182-1188. [CrossRef]

18. Hosseinpour-Mashkani, S.M.; Ramezani, M.; Sobhani-Nasab, A.; Esmaeili-Zare, M. Synthesis, characterization, and morphological control of $\mathrm{CaCu}_{3} \mathrm{Ti}_{4} \mathrm{O}_{12}$ through modify sol-gel method. J. Mater. Sci. Mater. Electron. 2015, 26, 6086-6091. [CrossRef]

19. Osman, A.I.; Abu-Dahrieh, J.K.; Abdelkader, A.; Hassan, N.M.; Laffir, F.; McLaren, M.; Rooney, D. Silver-Modified $\eta-\mathrm{Al}_{2} \mathrm{O}_{3}$ Catalyst for DME Production. J. Phys. Chem. C 2017, 121, 25018-25032. [CrossRef] 
20. Osman, A.I.; Abu-Dahrieh, J.K.; Rooney, D.W.; Thompson, J.; Halawy, S.A.; Mohamed, M.A. Surface hydrophobicity and acidity effecton alumina catalyst in catalytic methanoldehydration reaction. J. Chem. Technol. Biotechnol. 2017, 92, 2952-2962. [CrossRef]

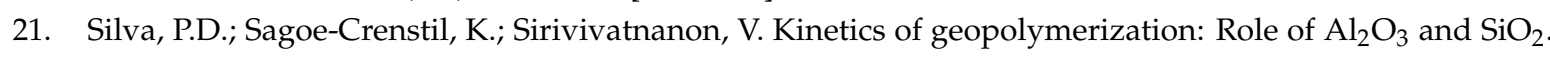
Cem. Concr. Res. 2007, 37, 512-518. [CrossRef]

22. Aramendía, M.A.; Boráu, V.; Jiménez, C.; Marinas, J.M.; Porras, A.; Urbano, F.J. Synthesis and characterization of $\mathrm{MgO}-\mathrm{B}_{2} \mathrm{O}_{3}$ mixed oxides prepared by coprecipitation; selective dehydrogenation of propan-2-ol. J. Mater. Chem. 1999, 9, 819-825. [CrossRef]

23. He, J.; Li, H.; Liu, Y.; Zhao, W.; Yang, T.; Xue, W.; Yang, S. Catalytic transfer hydrogenation of ethyl levulinate into $\gamma$-valerolactone over mesoporous $\mathrm{Zr} / \mathrm{B}$ mixed oxides. J. Ind. Eng. Chem. 2016, 43, 133-141. [CrossRef]

24. Soltani, S.; Rashid, U.; Al-Resayes, S.I.; Nehdi, I.A. Sulfonated mesoporous ZnO catalyst for methyl esters production. J. Clean. Prod. 2017, 144, 482-491. [CrossRef]

25. Kaur, M.; Ali, A. Lithium ion impregnated calcium oxide as nano catalyst for the biodiesel production from karanja and jatropha oils. Renew. Energy 2011, 36, 2866-2871. [CrossRef]

26. Mazaheri, H.; Ong, H.C.; Masjuki, H.H.; Amini, Z.; Harrison, M.D.; Wang, C.T.; Kusumo, F.; Alwi, A. Rice bran oil based biodiesel production using calcium oxide catalyst derived from Chicoreus brunneus shell. Energy 2018, 144, 10-19. [CrossRef]

27. Ye, X.; Wang, W.; Zhao, X.; Wen, T.; Li, Y.; Ma, Z.; Wen, L.; Ye, J.; Wang, Y. The role of the $\mathrm{KCaF}_{3}$ crystalline phase on the activity of KF/CaO biodiesel synthesis catalyst. Catal. Commun. 2018, 116, 72-75. [CrossRef]

28. Gupta, A.R.; Rathod, V.K. Calcium diglyceroxide catalyzed biodiesel production from waste cooking oil in the presence of microwave: Optimization and kinetic studies. Renew. Energy 2018, 121, 757-767. [CrossRef]

29. Li, J.; Wei, J.; Feng, Y.; Li, X. Effect of $\mathrm{CaO}$ on phase composition and properties of aluminates for barium tungsten cathode. Materials 2018, 11, 1380. [CrossRef]

30. Fadhil, A.B.; Al-Tikrity, E.T.B.; Khalaf, A.M. Transesterification of non-edible oils over potassium acetate impregnated $\mathrm{CaO}$ solid base catalyst. Fuel 2018, 234, 81-93. [CrossRef]

31. Roschat, W.; Phewphong, S.; Thangthong, A.; Moonsin, P.; Yoosuk, B.; Kaewpuang, T.; Promarak, V. Catalytic performance enhancement of $\mathrm{CaO}$ by hydration-dehydration process for biodiesel production at room temperature. Energy Convers. Manag. 2018, 165, 1-7. [CrossRef]

32. Suryaputra, W.; Winata, I.; Indraswati, N.; Ismadji, S. Waste capiz (Amusium cristatum) shell as a new heterogeneous catalystfor biodiesel production. Renew. Energy 2013, 50, 795-799. [CrossRef]

33. Lee, S.L.; Wong, Y.C.; Tan, Y.P.; Yew, S.Y. Transesterification of palm oil to biodiesel by using waste obtuse hornshell-derived CaO catalyst. Energy Convers. Manag. 2015, 93, 282-288. [CrossRef]

34. Mardhiah, H.H.; Ong, M.H.C.; Masjuki, H.H.; Lim, S.; Pang, Y.L. Investigation of carbon-based solid acid catalyst from Jatropha curcas biomass in biodiesel production. Energy Convers. Manag. 2017, 144, $10-17$. [CrossRef]

35. Granados, M.L.; Poves, M.D.Z.; Alonso, D.M.; Mariscal, R.; Galisteo, F.C.; Moreno-Tost, R.; Santamaría, J.; Fierro, J.L.G. Biodiesel from sunflower oil by using activated calcium oxide. Appl. Catal. B Environ. 2007, 73, 317-326. [CrossRef]

36. Shi, M.; Zhang, P.; Fan, M.; Jiang, P.; Dong, Y. Influence of crystal of $\mathrm{Fe}_{2} \mathrm{O}_{3}$ in magnetism and activity of nanoparticle $\mathrm{CaO} @ \mathrm{Fe}_{2} \mathrm{O}_{3}$ for biodiesel production. Fuel 2017, 197, 343-347. [CrossRef]

37. Tan, Y.H.; Abdullah, M.O.; Nolasco-Hipolito, C.; Taufiq-Yap, Y.H. Waste ostrich- and chicken-eggshells as heterogeneous base catalyst for biodiesel production from used cooking oil: Catalyst characterization and biodiesel yield performance. Appl. Energy 2015, 160, 58-70. [CrossRef]

38. Roschat, W.; Siritanon, T.; Yoosuk, B.; Promarak, V. Biodiesel production from palm oil using hydrated lime-derived $\mathrm{CaO}$ as a low-cost basic heterogeneous catalyst. Energy Convers. Manag. 2016, 108, 459-467. [CrossRef]

39. Yan, B.; Zhang, Y.; Chen, G.; Shan, R.; Ma, W.; Liu, C. The utilization of hydroxyapatite-supported CaO-CeO 2 catalyst for biodiesel production. Energy Convers. Manag. 2016, 130, 156-164. [CrossRef]

40. Osman, A.I.; Meudal, J.; Laffir, F.; Thompson, J.; Rooney, D. Enhanced catalytic activity of Ni on $\eta-\mathrm{Al}_{2} \mathrm{O}_{3}$ and ZSM-5 on addition ofceria zirconia for the partial oxidation of methane. Appl. Catal. B Environ. 2017, 212, 68-79. [CrossRef] 
41. Pan, H.; Li, H.; Zhang, H.; Wang, A.; Jin, D.; Yang, S. Effective production of biodiesel from non-edible oil using facile synthesis of imidazolium salts-based Brønsted-Lewis solid acid and co-solvent. Energy Convers. Manag. 2018, 166, 534-544. [CrossRef]

42. Pathak, G.; Das, D.; Rajkumari, K.; Rokhum, L. Exploiting waste: towards a sustainable production of biodiesel using Musa acuminata peel ash as a heterogeneous catalyst. Green Chem. 2018, 20, 2365-2373. [CrossRef]

43. Nongbe, M.C.; Ekou, T.; Ekou, L.; Yao, K.B.; Grognec, E.L.; Felpin, F.X. Biodiesel production from palm oil using sulfonated graphene catalyst. Renew. Energy 2017, 106, 135-141. [CrossRef]

44. Monteiro, M.R.; Ambrozin, A.R.P.; Lião, L.M.; Ferreira, A.G. Determination of biodiesel blend levels in different diesel samples by ${ }^{1} \mathrm{H}$ NMR. Fuel 2009, 88, 691-696. [CrossRef]

45. Hammond, C.; Conrad, S.; Hermans, I. Simple and scalable preparation of highly active Lewis acidic Sn- $\beta$. Angew. Chem. Int. Ed. 2012, 51, 11736-11739. [CrossRef] [PubMed]

46. Cano, R.; Schmidt, A.F.; McGlacken, G.P. Direct arylation and heterogeneous catalysis: Ever the twain shall meet. Chem. Sci. 2015, 6, 5338-5346. [CrossRef] [PubMed]

(C) 2018 by the authors. Licensee MDPI, Basel, Switzerland. This article is an open access article distributed under the terms and conditions of the Creative Commons Attribution (CC BY) license (http:/ / creativecommons.org/licenses/by/4.0/). 